\title{
ASPECTS OF ECOLOGY AND BIOGEOGRAPHY OF ACANTHOCEPHALA IN ANTARCTIC SEABIRDS
}

\author{
E. P. HOBERG*
}

\begin{abstract}
SUMMARY. Four species of acanthocephalans are reported from seabirds, nototheniid fishes and gammaridean amphipods in the western Antarctic. Corynosoma hamanni (von Linstow, 1892) was found in Phalacrocorax atriceps King, Chionis alba (Gmelin), Larus dominicanus Lichtenstein, and Catharacta lonnbergi (Mathews). The complete life cycle of this acanthocephalan was elucidated: cysticanths develop in the haemocoel of a gammaridean amphipod, Pontogeneiella sp. of the family Eusiridae and presumably, following ingestion of parasitized amphipods, encyst in the body cavity of antarctic fishes of several species. Corynosoma singularis Skriabin and Nikol'skii, 1971 was found only in $P$. atriceps. Corynosoma bullosum (von Linstow, 1892) occurred in both $P$. atriceps and Pygoscelis papua (Forster). Neither of these species of Corynosoma had previously been reported from avian hosts. Corynosoma shackletoni Zdzitowiecki, 1978 was recorded only as a parasite of $P$. papua. The first known gravid females of this species were found during this study, indicating that $C$. shackletoni is a typical parasite of avian, rather than mammalian, final hosts. It is the first acanthocephalan known to typically occur in an avian definitive host in Antaretica. The host-distribution of Corynosoma spp. in hirds suggested that these parasites were being acquired from piscine or possibly amphipod prey, generally in nearshore situations. Seabirds representing the zooplanktivore feeding guild were not infected. This indicates that pelagic foodwebs, and other trophic pathways in which Euphausia superba Dana is a dominant prey organism, are probably not involved in the life cycles of Corynosoma spp. The host and geographic distributions of Corynosoma in piscine, avian, and mammalian hosts suggested that oceanographic factors, particularly the Antartic Convergence, could limit the ranges for some species of parasites. Hostparasite coevolution appears to have had an important influence on the species composition of the acanthocephalan fauna of seabirds and marine mammals in Antarctica.
\end{abstract}

\section{Données écologiques et biogéographiques sur les Acantocéphales d'Oiseaux marins antarctiques}

RÉSUMÉ. Quatre espèces d'Acanthocéphales sont signalése chez des Oiseaux de mer, des Poissons (Nototheniidae) et des Amphipodes (Gammarides) de l'Antarctique occidental. Corynosoma hamanni (von Linstow, 1892) a été trouvé chez Phalacrocorax atriceps King, Chionis alba (Gmelin), Larus dominicanus Lichtenstein, et Catharacta lonnbergi (Mathews). Le cycle biologique de cet Acanthocéphale a été élucidé : les cysticanthes se développent dans l'hémocèle d'un Gammaride, Pontogeneiella sp. (Eusiridae), et vraisemblablement, à la suite de l'ingestion d'Amphipodes parasités, s'enkystent dans la cavité générale de plusieurs espèces de Poissons antarctiques. Corynosoma singularis Skriabin et Nikol'skii est trouvé seulement chez $P$. atriceps. Corynosoma bullosum (von Linstow, 1892) est présent à la fois chez P. atriceps et Pygoscelis papua (Forster).

- Dept. of Pathobiology SC-38, University of Washington, Seattle, WA. 98195 USA.

Accepté le 29 avril 1985 . 
Aucune de ces espèces de Corynosoma n'avait été trouvée auparavant chez des Oiseaux. Corynosoma shackletoni Zdzitowiecki, 1978 est signalée seulement comme parasite de $P$. papua. Les femelles gravides de cette espèce sont trouvées pour la première fois, ce qui indique que $C$. shackletoni est un parasite typique d'Oiseaux plutôt que de Mammifères. C'est le premier Acanthocéphale connu ayant un Oiseau comme hôte définitif dans la faune antarctique.

J.e spectre d'hôtes de Corynosoma spp. chez des Oiseaux marins suggère que ces parasites ont été acquis à partir de l'ingestion d'une proie (Poisson ou peut-être Amphipode), généralement dans des sites proches du rivage. Les (Oiseaux marins dont la nourriture est à base de zooplancton ne sont pas infestés. Ceci indique que les chaînes alimentaires pélagiques et autres modes trophiques dans lesquels domine Euphausia superba Dana n'interviennent pas dans le cycle biologique de Corynosoma spp. L'hòte et la distribution géographique de Corynosoma chez des Poissons, des Oiseaux et des Mammifères suggèrent que les facteurs océanographiques, en particulier la Convergence Antarctique, pourraient limiter la zone de répartition de certains de ces parasites. La co-évolution de l'hôte et du parasite semble avoir eu une influence importante sur la composition de la faune des espèces d'Acanthocéphales des Oiseaux marins et des Mammifères marins dans l'Antarctique.

Acanthocephalans of the genus Corynosoma Lühe, 1904 constitute a major component of the helminth fauna of marine mammals in the Antarctic and Subantartic (von Linstow, 1892 ; Rennie, 1907; Railliet and Henry, 1907; Leiper and Atkinson, 1915 ; Baylis, 1929; Edmonds, 1955, 1957 ; Golvan, 1959 ; Holloway and Bier, 1967 ; and others). However, there are relatively few records of this genus from seabirds in these geographic regions (Johnston and Edmonds, 1953 ; Edmonds, 1955 ; Holloway and Bier, 1967 ; Jones and Williams, 1969 ; Williams et al., 1974 ; Zdzitowiecki, 1978a, 1978b). Avian hosts are generally regarded as incidental in the life cycles of Corynosoma spp. that have geographic distributions restricted to high latitudes in the Southern Hemisphere.

In 1982, an intensive study of ecology, biogeography, and systematics of helminths infecting antarctic seabirds was initiated at Palmer Station, Anvers Island (see Holdgate, 1965 ; Parmelee et al., 1977 for site descriptions) and areas adjacent to the Antarctic Peninsula (Hoberg, 1983, 1984a, 1985).

Specimens of Corynosoma referrable to four species were found in charadriiform, pelecaniform and sphenisciform birds, nototheniid fishes, and gammaridean amphipods. Prior to this study, first intermediate hosts for Corynosoma had not been known in the Southern Hemisphere. It is the purpose of the present paper to report details of host-occurrence and geographic distributions of these acanthocephalans, and to consider some of their ecological relationships.

\section{Methods and materials}

During the austral summer of 1982-1983, 338 seabirds representing 14 species were collected in several areas adjacent to the Antarctic Peninsula : notably, Arthur Harbor, Anvers Island (Palmer Station) and vicinity; The Bransfield Strait and Gerlache Strait; and Admiralty Bay, King George Island (fig. 1). The birds were 


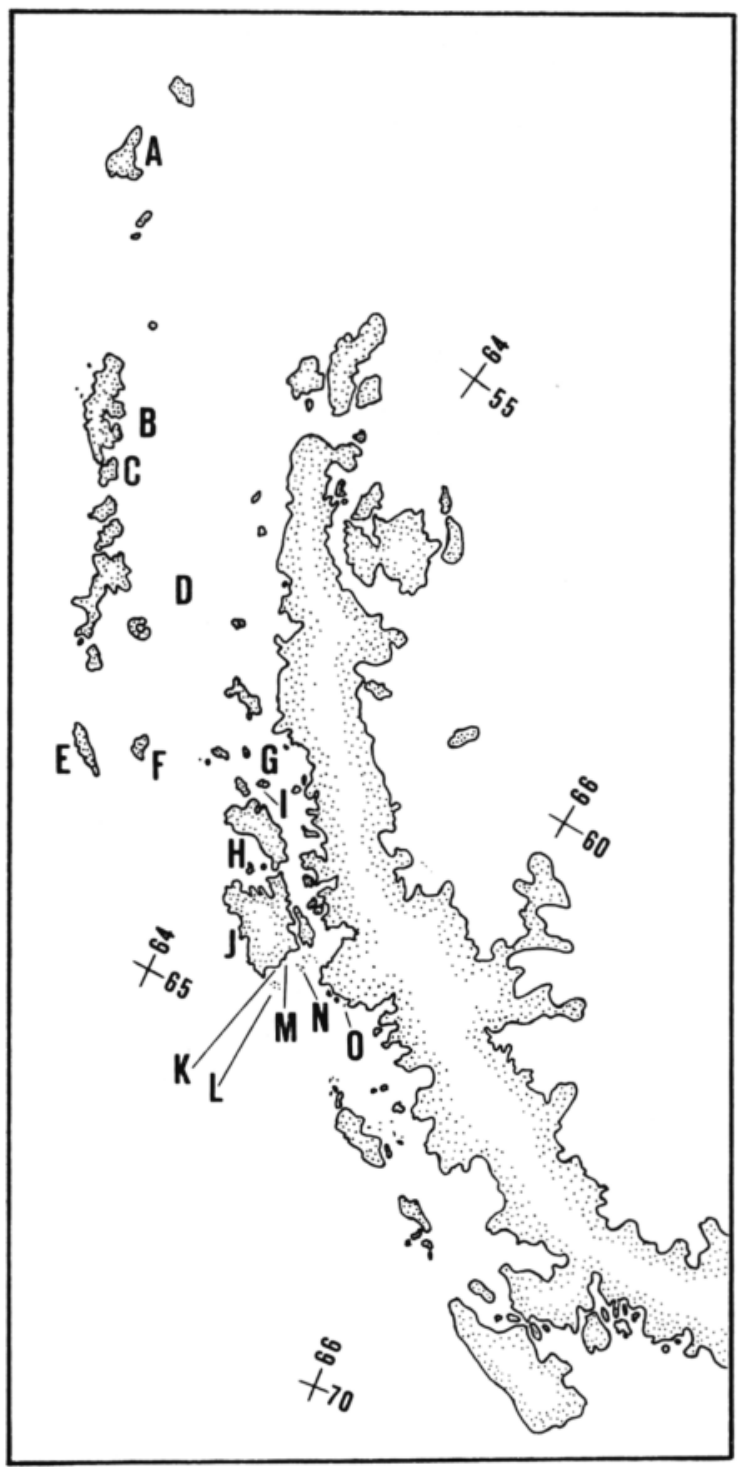

FIG. I. - Localities adjacent to the Antarctic Peninsula where specimens of seabirds, fishes and amphipods were collected.

South Shetland Islands : A) Elephant Island. B) King George Island (including Admiralty Bay and Demay Point). C) Nelson Island. D) Bransfield Strait (near Deception Island). E) Smith Island. F) Low Island. Palmer Archipelago : G) Gerlache Strait. H) Daılman Bay, Anvers Island. I) Two Hummock Island. J) Anvers Island. IK) Arthur Harbor (including Bonaparte and Norsel Point, and Torgersen, Humble, Shortcut, Steppingstones, Cormorant, Laggard and Limitrophe Islands). L) Ioubin Islands. M) Biscoe Point. N) Wauwermans Islands. O) Yalour Island. 
generally necropsied immediately following collection. Acanthocephalans were detached from the intestinal mucosa, allowed to relax in water until the proboscis was fully evaginated, and then fixed in hot $10 \%$ formalin. Specimens were stained in Semichon's acetic carmine and mounted entire. An additional 63 specimens of birds (principally pygoscelid penguins) collected in 1981 and 1982 at Elephant Island, Smith Island, Yalour Island and Nelson Island and in the Gerlache Strait were provided by R. W. Risebrough and A. M. Springer. Nototheniid fishes examined lor larval acanthocephalans, were collected by hook and line or by trawling nearshore in Arthur Harbor adjacent to Palmer Station (Notothenia coriiceps Richardson) and by trawling off Low Island near the Bransfield Strait ( $N$. gibberifrons Lonnberg). Amphipods were collected using dip-nets in shallow littoral areas, by trawling and from the stomach contents of fishes. Larvae recovered from fish were allowed to excyst in water and fixed as above. They were prepared as whole-mounts according to the methods previously described.

Differences in the prevalence of infection between age classes of hosts (Phalacrocorax atriceps King) were compared by $\chi^{2}$ analysis.

\section{Results}

Seabirds of 15 species were examined. Specimens of Corynosoma were found in gentoo penguins, Pygoscelis papua (Forster), blue-eyed shags, Phalacrocorax atriceps King, a southern black-backed gull, Larus dominicanus Lichtenstein, a brown skua, Catharacta lonnbergi (Mathews), and American sheathbills, Chionis alba (Gmelin) (Table I). Other species of birds broadly representing the zooplanktivore guild, were not found to be infected (Table II). Cysticanths were found in specimens of Notothenia coriiceps, N. gibberifrons, Notothenia sp. and Trematomus sp. and also in several gammaridean amphipods. Details of these infections in vertebrate and invertebrate hosts are presented below. Voucher specimens were deposited in the Helminthological Collections of the U. S. National Museum.

Corynosoma shackletoni Zdzitowiecki, 1978. USNM Helm. Coll. No. 78569, 78938. Sexually mature males and gravid females of this species were found only in Pygoscelis papua at King George Island and Elephant Island (Table I). They were always localized in the posterior $1 / 8$ of the small intestine of the host. Morphological details of these specimens will be considered elsewhere.

Remarks : Zdzitowiecki (1978a, 1978b) described this species on the basis of a mature male from a southern black-backed gull at King George Island, and from cysticanths from a fish, Parachaenichthys georgianus (Fischer), from South Georgia. Gravid specimens were not obtained, and it was suggested that $C$. shackletoni might be typically a parasite of marine mammals rather than of seabirds (Zdzitowiecki, 1978a). However, gravid specimens from birds found during the present study indicate that this acanthocephalan is a parasite of avian hosts. Edmonds (1955) reported a species of Corynosoma from Pygoscelis papua at Macquarie Island, and perhaps these were referrable to $C$. shackletoni. 
Table I. - Corynosoma spp. from species of seabirds in Antarctica ${ }^{a}$.

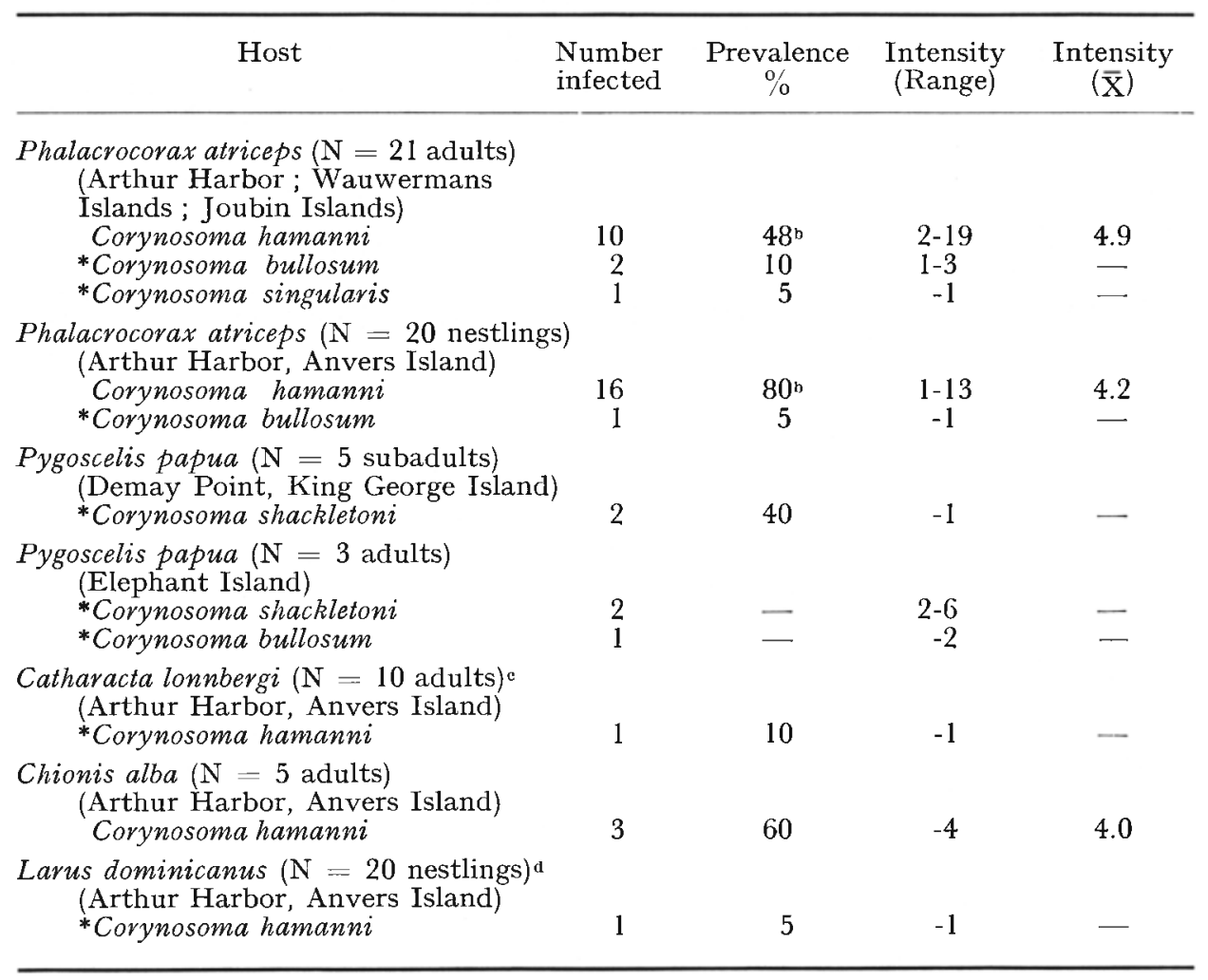

a) All records represent new geographic distributions for Corynosoma spp. in avian hosts except for C. shackletoni in Pygoscelis papua and C. hamanni in Phalacrocorax atriceps at King George Island.

b) Difference in prevalence of infection is significant $(p<.05)$ when comparing C. hamanni in adult and nestling shags.

c) Two nestling brown skuas examined were not infected.

d) Sixteen adult southern black-backed gulls from Arthur Harbor and five from the the Wauwermans Island were not infected.

* New host record.

Corynosoma hamanni (von Linstow, 1892). USNM Helm. Coll. No. 78571. $C$. hamanni was the most common acanthocephalan encountered in seabirds and fishes, and the only species found in amphipods. Immature males and females were common in adult and nestling Phalacrocorax atriceps (difference in prevalence between age classes was significant $\left.: \chi^{2}=4.64 ; 1 \mathrm{df} ; p<.05\right)$, and adult Chionis alba, but rare in both Catharacta lonnbergi and Larus dominicanus (Table I). In avian hosts, C. hamanni was typically localized in the posterior third of the small intestine, although specimens were recovered from the large intestine and the proventriculus (attached) of a nestling and of two adult $P$. atriceps, respectively. 
TABLE II. - Species of seabirds examined for acanthocephalan parasites, but found to be free of infection.

\begin{tabular}{|c|c|c|c|}
\hline Species & $\begin{array}{l}\text { Number } \\
\text { adults }\end{array}$ & $\begin{array}{l}\text { amined } \\
\text { nestlings }\end{array}$ & Geographic locality \\
\hline \multirow{2}{*}{$\begin{array}{l}\text { Pygoscelis adeliae } \\
\text { (Hombron \& Jacquinot) }\end{array}$} & 20 & 20 & Arthur Harbor \\
\hline & 1 & 20 & $\begin{array}{l}\text { Admiralty Bay } \\
\text { Yalour Island }\end{array}$ \\
\hline \multirow{2}{*}{$\begin{array}{l}\text { Pygoscelis antarctica } \\
\text { (Forster) }\end{array}$} & 7 (subadults) & & Arthur Harbor \\
\hline & $\begin{array}{r}4 \\
5 \\
14 \\
20\end{array}$ & $\begin{array}{r}6 \\
10\end{array}$ & $\begin{array}{l}\text { Demay Point } \\
\text { Joubin Islands } \\
\text { Smith Island } \\
\text { Nelson Island }\end{array}$ \\
\hline $\begin{array}{l}\text { Eudvptes chrysolophus } \\
\text { (Brandt) }\end{array}$ & 1 & & Smith Island \\
\hline \multirow{2}{*}{$\begin{array}{l}\text { Fulmarus glacialoides } \\
\text { (Smith) }\end{array}$} & 9 & & Two Hummock Island \\
\hline & $\begin{array}{l}5 \\
4\end{array}$ & & $\begin{array}{l}\text { Gerlache Strait } \\
\text { Bransfield Strait }\end{array}$ \\
\hline \multirow{2}{*}{$\begin{array}{l}\text { Pagadroma nivea } \\
\text { (Forster) }\end{array}$} & 7 & & Two Hummock Island \\
\hline & 6 & & Dallman Bay \\
\hline \multirow{2}{*}{$\begin{array}{l}\text { Daption capensis } \\
\text { (Linnaeus) }\end{array}$} & 2 & & Two Hummock Island \\
\hline & $\begin{array}{r}7 \\
13\end{array}$ & & $\begin{array}{l}\text { Admiralty Bay } \\
\text { Bransfield Strait }\end{array}$ \\
\hline \multirow{2}{*}{$\begin{array}{l}\text { Oceanites oceanicus } \\
\text { (Kuhl) }\end{array}$} & 20 & & Arthur Harbor \\
\hline & $\begin{array}{r}5 \\
1 \\
11\end{array}$ & & $\begin{array}{l}\text { Two Hummock Island } \\
\text { Bransfield Strait } \\
\text { Admiralty Bay }\end{array}$ \\
\hline \multirow{2}{*}{$\begin{array}{l}\text { Macronectes giganteus } \\
\quad(\mathrm{Gmelin})\end{array}$} & 18 & 15 & Arthur Harbor \\
\hline & $\begin{array}{l}1 \\
1\end{array}$ & & $\begin{array}{l}\text { Bransfield Strait } \\
\text { Admiralty Bay }\end{array}$ \\
\hline \multirow{2}{*}{$\begin{array}{l}\text { Sterna vittata } \\
\quad \text { (Gmelin) }\end{array}$} & 10 & & Arthur Harbor \\
\hline & $\begin{array}{r}10 \\
1\end{array}$ & & $\begin{array}{l}\text { Joubin Islands } \\
\text { Admiralty Bay }\end{array}$ \\
\hline $\begin{array}{l}\text { Catharacta maccormicki } \\
\text { (Saunders) }\end{array}$ & 20 & & Arthur Harbor \\
\hline
\end{tabular}

Cysticanths of $C$. hamanni were numerous in Notothenia gibberifrons from Low Island (Number examined $=10$; Prevalence $=80 \%$; Range in intensity $=2-9$; $\overline{\mathrm{X}}=6.6 \pm 2.9$ parasites per infected host) and $N$. coriiceps from Arthur Harbor $(\mathrm{N}=35 ;$ Prevalence $=94 \%$; Range $=2-108 ; \overline{\mathrm{X}}=23 \pm 20.9)$. The largest fish, from $258-405 \mathrm{~mm}$ in standard length, were the most heavily parasitized. In an additional sample of smaller fish, 47-108 mm in length, only 4 of 19 Notothenia sp. and 
Trematomus sp. from Low Island and Arthur Harbor were infected (Prevalence = $21 \%$; Range $=1-5$ ). Larvae were localized in the mesenteric connective tissue surrounding the pyloric caecae, in the liver, kidney, stomach wall, or free in the lumen of the intestine. Cysts occurred singly or in grape-like clusters. Additionally, five cysticanths were recovered from the haemocoel of a species of Pontogeneiella Schellenberg, 1929, a gammaridean amphipod of the family Eusiridae, collected near Low Island.

Remarks: Specimens infecting birds were all immature with the exception of one female (of 51), in which ovarian balls were observed. Generally, there was no difference in degree of development of genital organs in specimens from birds, fishes or amphipods. Those studied ( 27 from birds, 32 from fishes, and 2 from amphipods) had 18-22 rows of hooks with 11-16 hooks per row (the last 2-3 being large spines). The extent of spination on the trunk in males and females was identical to previous descriptions of C. hamanni (Edmonds, 1957 ; Jones and Williams, 1969 ; Holloway and Nickol, 1970 ; Zdzitowiecki, 1978b ; and others). They were also generally similar in the form of the lemnisci and the relative length of the proboscis receptacle. However, in some specimens the proboscis receptacle was substantially longer than the lemnisci and extended well into the posterior half of the trunk. Variation in body size was apparent in specimens from avian and piscine hosts. Range in total body length in cysticanths and immature $C$. hamanni was 1.53-2.2 in charadriiform birds, and up to $3.1 \mathrm{~mm}$ in $P$. atriceps and $3.4 \mathrm{~mm}$ in Notothenia spp.

Corynosoma hamanni is a typical parasite of Weddell seals, Leptonychotes weddelli Lesson, Ross seals, Ommatophoca rossi Gray, leopard seals, Hydrurga leptonyx de Blainville, and crabeater seals, Lobodon carcinophaga Hombron and Jacquinot in the Antarctic (Leiper and Atkinson, 1915; Edmonds, 1957; Holloway and Bier, 1967 ; Golvan, 1959 ; and others). Several other species, morphologically similar to C. hamanni, have been described from marine mammals in the Antarctic and Subantarctic. These include C. antarcticum (Rennie, 1907), C. sipho Railliet and Henry, 1907 from Weddell seals and C. pacifica Nikol'skii, 1974 from Weddell and leopard seals. These, along with $C$. hamanni, differ from other species of Corynosoma from antarctic pinnipeds in possessing a continuous ventral field of trunk spines (Rennie, 1907 ; Railliet and Henry, 1907 ; and Nikol'skii, 1974). A specimen similar to C. validum Van Cleave, 1953, from Trematomus sp. or Notothenia sp. in the South Shetland Islands may be referrable to one of these nominal taxa (see Van Cleave, 1953 ; pg. 84). Leiper and Atkinson (1915) and Edmonds (1957) suppressed both C. antarcticum and $C$. sipho as synonyms of C. hamanni. However, Meyer (1933), Petrochenko (1958), Deliamure (1955), Golvan (1959), and Nikol'skii (1974) considered C. sipho to be valid while reducing $C$. antarcticum as a synonym of $C$. hamanni.

C. hamanni was characterized by a proboscis armed with 18-21 rows of hooks with 12-15 per row by Edmonds (1957) ; 18-23 rows with 11-15 hooks by Nickol and Holloway (1968); and 19-22 rows with 11-17 hooks by Zdzitowiecki (1978b). In C. antarcticum, Johnston and Best (1937) found 18 rows of hooks with 14-15 per row and in $C$. sipho, Railliet and Henry (1907) found 21-22 rows each with 11 hooks. Nikol'skii (1974) characterized C. pacifica as having 20-22 rows of 14-16 hooks. 
According to these authorities, the size of the egg was one of few morphological characters that could be consistently used to separate these species (also see Holloway and Nickol, 1970).

It is apparent that larval specimens from fishes and amphipods, and sexually immature forms from birds, reported in this study, cannot be reliably referred to any of the species mentioned above. As there is some confusion about the validity of these nominal taxa, it seems preferable to refer all of the present specimens to C. hamanni sensu lato, much as Zdzitowiecki (1978b) concluded for cysticanths collected from species of antarctic fishes in the South Shetland Islands and at South Georgia.

Prior to the present study, $C$. hamanni was the only acanthocephalan commonly reported from seabirds at other localities in Antarctica. At McMurdo Sound, Holloway and Bier (1967) examined 86 birds, including 48 Pygoscelis adeliae, 37 Catharacta maccormicki and an Aptenodytes forsteri Gray, and only found a single female in an adelie penguin. Jones and Williams (1969) and Williams et al. (1974) found immature specimens in Chionis alba in the South Orkney Islands and at South Georgia. Zdzitowiecki (1978b) first reported C. hamanni from Phalacrocorax atriceps at King Creorge Island. Specimens of $C$. hamanni apparently have not been found previously in Larus dominicanus and Catharacta lonnbergi.

Cysticanths of $C$. hamanni have been recorded from antarctic fishes of 12 species representing four families (Nototheniidae, Bathydraconidae, Zoarcidae, and Chaenichthyidae) (Baylis, 1929 ; Holloway and Bier, 1967; Markowski, 1971 ; Zdzitowiecki, 1978b; Holloway and Spence, 1980 ; and others). Both Notothenia coriiceps and $N$. gibberifrons have been recognized as paratenic hosts. However, cysticanths in gammaridean amphipods have not been reported for any species of Corynosoma in the Antarctic or the Southern Hemisphere. Natural infections of cysticanths in the haemocoel of Pontogeneiella sp. clearly establish this littoral amphipod as one of probably several intermediate hosts for C. hamanni. Holloway and Bier (1967) were unsuccessful in attempts to establish experimental infections of $C$. hamanni in amphipods of the genus Orchomonella Sars (= Orchomene Boek), family Lysianassidae, at McMurdo Sound.

Corynosoma singularis Skriabin and Nikol'skii, 1971. USNM Helm. Coll. No. 78570. A single immature male of this parasite was localized in the posterior fourth of the small intestine of an adult Phalacrocorax atriceps at Arthur Harbor (Table I). A cysticanth was found in the mesenteric connective tissue of one of 35 Notothenia coriiceps also from Arthur Harbor. These specimens agreed morphologically with the redescription of this species provided by Zdzitowiecki (1978b).

Remarks : $C$. singularis was originally described from specimens infecting Hydrurga leptonyx and Physeter catadon Linnaeus, in Antarctica (Skriabin and Nikol'skii, 1971) while Nikol'skii (1974) provided an additional record from leopard seals. Cysticanths have been found in Notothenia rossi Richardson in the South Shetland Islands and at South Georgia (Zdzitowiecki, 1978b). C. singularis has not been reported previously from an avian host or from Notothenia coriiceps.

Corynosoma bullosum (von Linstow, 1892). USNM Helm. Coll. No. 78572, 78573. 
Immature specimens of $C$. bullosum were found in adult and nestling Phalacrocorax atriceps at Arthur Harbor and in an adult Pygoscelis papua at Elephant Island (Table I). The acanthocephalans were localized in the posterior fourth of the small intestine, except for two specimens attached to the mucosa of the proventriculus of one $P$. atriceps. Cysticanths were found in mixed infections with $C$. hamanni in the mesenteric connective tissue of Notothenia coriceps $(\mathrm{N}=35$; Prevalence $=20 \%$; Range in intensity $=1-5 ; \overline{\mathrm{X}}=1.6 \pm 1.63$ ) from Arthur Harbor and $N$. gibberifrons $(\mathrm{N}=10$; Prevalence $=20 \%$; Range $=2-3)$. These specimens agreed with the redescriptions of $C$. bullosum prepared by Edmonds (1957), Nikol'skii (1974) and Zdzitowiecki (1978b).

Remarks: Corynosoma bullosum is a typical parasite of marine mammals including southern elephant seals, Mirounga leonina Linnaeus, Lobodon carcinophaga, and Hydrurga leptonyx in the Antarctic and Subantarctic (von Linstow, 1892 ; Baylis, 1929 ; Edmonds, 1957 ; and Nikol'skii, 1974). Cysticanths have been found in Parachaenichthys georgianus and Chaenocephalus aceratus (Lonnberg) at South Georgia, Notothenia coriiceps at Heard Island, and in $N$. coriiceps, $N$. rossi and $C$. aceratus in the South Shetland Islands (Baylis, 1929 ; Edmonds, 1957 ; Zdzitowiecki, 1978b). $C$. bullosum has apparently not been reported previously from an avian host, or from $N$ gibberifrons.

\section{Discussion}

Acanthocephalans of the genus Corynosoma are typical parasites of pinnipeds inhabiting the subantarctic and antarctic seas (Deliamure, 1955; Golvan, 1959; Holloway and Bier, 1967 ; and others) but occur only incidentally (with the exception of $C$. shackletoni and $C$. clavatum Goss, 1941) in avian final hosts (Goss, 1941; Johnston and Edmonds, 1953 ; Edmonds 1955 ; Jones and Williams, 1969 ; Williams et al., 1974; Zdzitowiecki, 1978a, 1978b). Generally, specimens of C. hamanni, $C$. singularis, and $C$. bullosum were not sexually mature or gravid when they occurred in seabirds and development usually did not proceed beyond that observed in cysticanths from fish. Holloway and Bier (1967) reported the development of ovarian balls in a female of $C$. hamanni from an adelie penguin at McMurdo Sound and only one female was found in a comparable state of development during the present study. In both the Arctic and the Antarctic, the marine acanthocephalan faunas of homeothermic vertebrates are dominated by species which only develop successfully in marine mammals while those typical of avian definitive hosts are rare (Van Cleave, 1953 ; Petrochenko, 1958 ; Golvan, 1959 ; Rausch, 1983 ; Hoberg, 1984b).

The complete cycle of only two species of Corynosoma is known in marine habitats. Petrochenko (1958) listed the amphipod, Pontoporeia affinis Lindstrom, as the first intermediate host for Corynosoma semerme (Forssell, 1904) and C. strumosum (Rudolphi, 1802). Data from the present study showed the first intermediate host of Corynosoma hamanni to be a gammaridean amphipod, Pontogeneiella sp., of the family Eusiridae. Other species of Corynosoma in the Antarctic probably 
have amphipods as first intermediate hosts, but no other complete cycle has been elucidated in the Southern Hemisphere. The genus Pontogeneiella is represented by two species, $P$. brevicornis (Chevreux, 1906) and $P$. longicornis (Chevreux, 1906), in the region of the Antarctic Peninsula. Both inhabit benthic-littoral habitats, nearshore, and have a depth range from near low tide to $310 \mathrm{~m}$ (Barnard, 1969 ; Lowry and Bullock, 1976). Amphipods of this genus have been reported as important prey for some nototheniid fishes in coastal areas (Targett, 1981; Hoberg, unpubl. data) including several species recognized as paratenic hosts (Zdzitowiecki, 1978b).

Although euphausiids are a dominant component in many marine food-webs in Antarctica (Knox, 1970 ; El-Sayed, 1971 ; Laws, 1977), data suggest these crustaceans are not intermediate hosts for Corynosoma spp. Kagei et al. (1978) did not find helminths of any kind in a sample of 55,000 Euphausia superba Dana collected in oceanic regions of the Pacific sector of the Antarctic. Species of Corynosoma considered in the present study have paratenic hosts which are predominantly benthic foragers associated with nearshore zones and coastal food-webs (see Zdzitowiecki, 1978b; Targett, 1981). In such communities euphausiids are often only of temporary importance to fish, while amphipods, polychaetes, and other invertebrates have been recognized as significant prey (Targett, 1981). Holloway and Bier (1967), Holloway (1967) and Holloway and Spence (1980) reported the incidence of infection by cysticanths of $C$. hamanni at McMurdo Sound to be significantly greater in fishes occurring in deep-water coastal areas rather than in those inhabiting shallow surface waters.

There are definable ecological limitations in the host-distribution of Corynosoma spp. in seabirds. It is apparent that life cycles are not generally completed in pelagic situations and through food-webs in which krill, particularly Euphausia superba, is a dominant prey for potential paratenic or final hosts.

Acanthocephalans were not found in a large sample of nearshore and pelagic foraging seabirds, broadly representative of the zooplanktivore feeding guild (Table II). The three species of pygoscelid penguins feed close to shore and utilize significant amounts of krill as prey but only Pygoscelis papua is known to consume substantial numbers of fishes (Volkman et al., 1980 ; Trivelpiece et al., 1983; Ainley et al., 1984). Euphausiids are recognized as being important in the diets of Catharacta maccormicki (Parmelee et al., 1978; Hoberg, unpubl. data) while nototheniid fishes may be mcre significant than krill for Sterna vittata (Watson, 1975 ; Hoberg, unpubl. data). Due to their small size, fish selected by antarctic terns are probably not often parasitized by cysticanths. Pelagic foraging zooplanktivores, including Daption capensis, Fulmarus glacialoides, Pagadroma nivea, and Oceanites oceanicus apparently have more diversified diets including varying quantities of euphausiids, along with cephalopods, amphipods, other crustacea, fishes, and polychaetes (Beck, 1969; Beck and Brown, 1972 ; Watson, 1975 ; Croxall and Prince, 1980 ; Ainley et al., 1984; Hoberg, unpubl. data). Carrion, in addition to pelagic prey is important for southern giant petrels (Johnstone, 1977 ; Croxall and Prince, 1980).

Acanthocephalans were common only in birds such as Phalacrocorax atriceps and Pygoscelis papua, which typically forage in nearshore habitats and regularly 
consume nototheniiform fishes of small to medium size (Watson, 1975 ; Volkman et al., 1980 ; Trivelpiece et al., 1983; Hoberg, unpubl. data). Species of Notothenia and Trematomus were the dominant prey of adult and nestling $P$. atriceps examined during the present study (standard length range $=85-135 \mathrm{~mm}$, based on ten whole fish in stomach contents). Such small fish were generally not heavily parasitized by cysticanths when compared with larger specimens of $N$. coriiceps and $N$. gibberifrons (also see Zdzitowiecki, 1978b). Infections of high intensity by Corynosoma might not be expected in adult or nestling $P$. atriceps due to the distribution of cysticanths in fishes utilized as prey. It is likely that acanthocephalans were acquired locally as indicated by the immature specimens in nestlings. The significant difference in prevalence of infection seen between age classes could be attributable to a lower degree of immunological competence in young birds.

Among charadriiform birds, Corynosoma hamanni was found frequently in Chionis alba, but rarely in Larus dominicanus and Catharacta lonnbergi. The former two species are often scavengers in littoral habitats, but also include amphipods and other invertebrates in their diet (Jones, 1963; Jones and Williams, 1969 ; Hoberg, unpubl. data). Adult $C$. lonnbergi feed predominantly on penguins and carrion during the breeding season, thus the occurrence of $C$. hamanni is notable (Trivelpiece and Volkman, 1982 ; Trivelpiece et al., 1980 ; Parmelee et al., 1978 ; and Hoberg unpubl. data). Infections in these birds were possibly acquired from invertebrate prey.

In the Southern Ocean only two species of Corynosoma are known to have seabirds as definitive hosts. Based on available data, both appear to have restricted host-distributions and are endemic to specific regions. In the Western Antarctic, C. shackletoni may be typical of penguins rather than other seabirds, including Phalacrocorax atriceps. In contrast, C. clavatum is characteristic of Phalacrocorax spp. only among the subantarctic islands of the Indian Ocean Sector (Edmonds, 1955, 1957) and in the vicinity of New Zealand and Australia (Goss, 1941 ; Johnston and Best, 1942 ; Johnston and Edmonds, 1953). Cysticanths of this species were reported from fish, Platycephalus fuscus off South Australia (Johnston and Edmonds, 1952). Among Corynosoma spp. from marine mammals, C. hamanni, C. singularis, C. sipho and $C$. pacifica could have ranges limited largely to the Antarctic while $C$. bullosum may occur most commonly in the Subantarctic (Nikol'skii, 1974; Zdzitowiecki, 1978b).

Regional endemism, influenced by the Antarctic Convergence (an oceanic frontal system delimiting the Antarctic from the Subantarctic) is also apparent among fishes (Andriashev, 1965 ; DeWitt, 1971) and invertebrates, including gammaridean amphipods (Ekman, 1953; Knox and Lowry, 1977), and to a lesser extent among seabirds and marine mammals (Watson et al., 1971 ; Repenning et al., 1979). The congruent geographic distributions of some Corynosoma spp. and their characteristic hosts suggests that coevolution influenced the development of this parasitehost assemblage. Although the coastal zones of the antarctic continent have been isolated in the Southern Ocean since the Paleocene (DeWitt, 1971) or Eocene (Woodburne and Zinsmeister, 1982) some components of the marine fauna are relatively 
young. The historical relationship of Corynosoma in the Antarctic probably date from the Miocene, coinciding with an extensive diversification among amphipods (Lowry and Bullock, 1976), marine mammals (Repenning et al., 1979) and seabirds (Rich, 1975 ; Simpson, 1975). The geographic distributions of some parasites may now be restricted as a consequence of coevolution and the endemic character of an array of typical intermediate, paratenic and final hosts. The Antarctic convergence could constitute a barrier to the dispersal of some Corynosoma spp. by limiting the ranges of suitable intermediate hosts.

Acknowledgements. Field studies were conducted at Palmer Station, Anvers Island and supported by National Science Foundation Grant DPP 8115975 to Dr. R. L. Rausch and the author. Dr. G. Shinn provided excellent support and assistance in all aspects of the field work. Some avian specimens from the Palmer Archipelago in 1982-1983 were collected by Mr. A. F. Betzel, Mr. B. S. Obst, and Dr. W. Hamner. Dr. R. W. Risebrough and Mr. A. M. Springer allowed the parasitological examination of additional avian specimens collected by them in 1981-1982, and provided facilities for these necropsies at the Bodega Bay Marine Laboratories, University of California. Specimens of fishes were provided by Dr. A. E. V. Haschemeyer and her colleagues. I am endebted to Capt. P. J. Lenie and the crew of $\mathrm{R} / \mathrm{V}$ Hero for logistical support during our work in Antarctica. Dr. J. J. Stretch kindly identified the specimens of amphipods. Dr. A. O'C. Deeney prepared the French summary. I should also like to thank Dr. R. L. Rausch for reviewing earlier versions of this manuscript and for many useful discussions.

\section{Addendum}

Since this paper went to press several articles became available concerning acanthocephalans of marine mammals and seabirds in Antarctica. Species of Corynosoma and Parafilicollis were reported from avian hosts including, Phalacrocorax atriceps (C. hamanni and C. pseudohamanni Zdzitowiecki, 1984), Chionis alba (Parafilicollis antarcticus Zdzitowiecki, 1985 ; Corynosoma sp.), Larus dominicanus (C. shachletoni) and Pygoscelis papua (C. shackletoni) at King George Island (Zdzitowiecki, 1985). Four new species of Corynosoma from pinnipeds in the South Shetland Islands were described (C. arctocephali Zdzitowiecki, 1984 ; C. evae Zdzitowiecki, 1984 ; C. hannae Zdzitowiecki, 1984 ; and C. pseudohamanni), while several others were redescribed (C. hamanni with $C$. sipho, $C$. antarcticum, and $C$. pacificum as synonyms; $C$. australe, Johnston, 1939 ; and $C$. bullosum) (Zdzitowiecki, 1984a; 1984b). Due to the apparent morphological similarities of some of these species (particularly C. hamanni and C. pseudohamanni; C. singularis and $C$. arctocephali) it became necessary to reevaluate the collections on which the present paper was based.

Corynosoma hamanni and C. pseudohamanni were both present in seabirds and nototheniid fishes, while only the latter species was found in gammaridean amphipods. Specimens now designated as C. hamanni (USNM Helm. Coll. Nos. 78939 ; 78940) had 1516 hooks per row with the largest being $81-87 \mu \mathrm{m}(\overline{\mathrm{X}}=83)$ long and agreed in details of trunk-spination with those redescribed by Zdzitowiecki (1984b). Acanthocephalans iden- 
tified as $C$. pseudohamanni (USNM Helm. Coll. No. 78571) had 11-14 hooks per row with the largest measuring 62-78 $\mu \mathrm{m}(\overline{\mathrm{X}}=69)$, and differed in the extent of trunk-spination when commpared to C. hamanni (Zdzitowiecki, 1984b).

The prevalence of $C$. pseudohamanni was significantly greater $\left(\chi^{2}>6.46 ; 1 \mathrm{df} ; p<\right.$ $0.01)$ than that of $C$. hamanni in adult and nestling Phalacrocorax atriceps, Notothenia gibberifrons, and $N$. coriciceps. New data for Table I and the text are as follows : adult $P$. atriceps $(C$. pseudohamanni: Prevalence $48 \%$; Intensity $1-19 ; \overline{\mathrm{X}}=5 ; C$. hamanni: Prevalence $5 \%$; Intensity 1), nestling $P$. atriceps (C. pseudohamanni: $65 \%$; $1-11$; $\overline{\mathrm{X}}=5 ;$ C. hamanni: $25 \% ; 1-2 ; \overline{\mathrm{X}}=2$ ), N. coriiceps (C. pseudohamanni : $89 \% ; 2-90$; $\overline{\mathrm{X}}=21 ; C$. hamanni: $17 \% ; 3-43 ; \overline{\mathrm{X}}=19)$ and $N$. gibberifrons $(C$. pseudohamanni: $80 \% ; 2-9 ; \overline{\mathrm{X}}=6 ;$ C. hamanni $: 10 \% ; 2$ ). Mixed infections of these species were rare : C. pseudohamanni and C. hamanni co-ocurred in adult (10\% of infected hosts) and nestling $(13 \%) P$. atriceps, $N$. corriceps $(12 \%)$ and $N$. gibberifrons $(13 \%)$.

All other specimens from charadriiforms and fish (Notothenia sp., Trematomus sp.) should now be designated as C. pseudohamanni. Larus dominicanus, Chionis alba, and Catharacta lonnbergi had not previously been reported as incidental hosts for this species (Zdzitowiecki, 1985). The first intermediate hosts for C. pseudohamanni are gammaridean amphipods, including Pontogeneiella spp., and all comments in the text concerning life cycles pertain to this acanthocephalan.

Specimens identified as $C$. singularis in the text and Table $\mathbf{I}$ should now be referred to C. arctocephali (USNM Helm. Coll. No. 78570). Material from Phalacrocorax atriceps and Notothenia coriiceps was in agreement with that described by Zdzitowiecki (1984a) and had 11-12 hooks per row, with the largest hooks located near the middle of the proboscis, measuring $74 \mu \mathrm{m}$. Corynosoma arctocephali had not previously been reported from an avian host.

Earlier conclusions concerning ecology and biogeography, have not been altered as a consequence of the reevaluation of collections from the region of Anvers Island. The ocurrence of Corynosoma spp. in the 14 species of seabirds examined by Zdzitowiecki (1985) supports general concepts about food-webs developed in the present sudy. The different species of acanthocephalans found in the avian hosts from the South Shetland Islands, particularly Corynosoma sp. and Parafilicollis antarcticus in Chionis alba, may reflect some degree of endemism. A notable difference in the distribution of Corynosoma spp. between Anvers Island and the South Shetland Islands appeared to be in the relative abundance of $C$. hamanni and $C$. pseudohamanni. The significantly greater prevalence of $C$. pseudohamanni in all paratenic and incidental hosts at Anvers Islands is in contrast to the situation reported by Zdzitowiecki $(1984 \mathrm{~b} ; 1985)$. In the South Shetlands C. hamanni and C. pseudohamanni generally occurred with near equal prevalence in paratenic hosts (66\% versus $76 \%$ respectively) while the former appeared to be more common in incidental avian hosts $(60 \%$ versus $20 \%$ ). These patterns, if not due to sampling error, may reflect a difference in distribution of typical final hosts for C. hamanni (Hydruga leptonyx Leptonychotes wedelli and Lobodon carcinophagus) and C. pseudohamanni (Leptonychotes weddelli and Lobodon carcinophagus) at the two localities.

\section{REFERENCES}

Ainley D. G., O'Conner E. F., Boekelheide R. J. : The marine ecology of birds in the Ross Sea, Antarctica. Ornithological Monogr., 1984, 32, 97 p.

Andriashev A. P.: A general review of the antarctic fish fauna. Chap. 15. In : Biogeography and Ecology in Antarctica (J. van Mieghen, P. van Oye, eds). W. Junk Publisher, The Hague, I965, 49I-550.

Barnard J. L.: The families and genera of marine Gammaridean Amphipoda. U. S. Nat. Mus. Bull., 1969, 27I, $535 \mathrm{P}$. 
BAylis H. A. : Parasitic nematoda and acanthocephala collected in 1925-1927. Discovery Repts., I929, $I, 54 \mathrm{I}-560$.

BECK J. R. : Food, moult and age at first breeding in the cape pigeon, Daption capensis Linnaeus. Br. Antarctic Surv. Bull., 1969, 2I, 33-44.

Beck J. R., Brown D. W. : The biology of Wilson's storm petrel, Oceanites oceanicus (Kuhl), at Signy Island, South Orkney Islands. Br. Antarctic Surv. Bull., I972, 69, I-54.

Croxall J. P., Prince P. A. : Food, feeding ecology and ecological segregation of seabirds at South Georgia. Biol. J. Linnean Soc. London, 1980, I4, 103-131.

Deliamure S. L. : Helminthofauna of marine mammals (Ecology and Phylogeny). Akad. Nauk SSSR. Gel'miniol. Lab. Enxish Translation, Israel Prog. Sci. Trans., Jerusalem, 1968, $522 \mathrm{p}$.

Dew? T H. H. : Coastal and deepwater benthic fishes of the Antarct c. Antarctic Map Folio Series I5. Am. Geog. Soc., I971, I-IO and Folio.

Edmonds S. J. : Acanthocephala collected by the Australian National Antarctic Expedition on Heard Island and Macquarie Island during 1948-50. Trans. Roy. Soc. S. Aust., I955, 78 , I 4 I-I 44 .

Edmonds S. J. : Acanthocephala. BANZ Antarctic Expedition 1929-193I. Rept. Series B. (Zoologyj. I957, $5,93-98$.

EкмAN S. : Zoogeography of the sea. Sidgwick and Jackson, London, 1953, 4 I 7 p.

EL-SAYED S. Z. : Dynamics of trophic relations in the Southern Ocean. In : Research in the Antarctic (L. O. Quan, H. D. Porter, eds.). Am. Assoc. Adv. Sci. Publ., 93, 197 I, 73-9I.

Golvan Y. J. : Acanthocephales du genre Corynosoma Lühe, I904. Parasites de mammifères d'Alaska et de Midway. Ann. Parasilol. Hum. Comp., r 959, 34, 288-32 I.

Goss O. M. : Platyhelminth and acanthocephalan parasites of local shags. J. Roy. Soc. W. A ust., I94I, I6, I-I3.

Hoberg E. P. - Preliminary comments on parasitological collections from seabirds at Palmer Station, Antarctica. Antarctic J.U. S., 1983, 18, 216-218.

Hoberg E. P. : Trematode parasites of birds in Antarctica : the distribution of Gymnophallus deliciosus (Olsson, 1893). Antarctic J.U.S., 1984a, 19, I59-160.

Hoвerg E. P. : Systematics, zoogeography, and ecology of paltyhelminth parasites of the seabird family Alcidae (Charadriiformes : Suborder Alcae). Unpublished Ph. D. Dissertation, University of Washington, I984b.

НовеRG E. P. : Reticuloiaenia gen. n. for Lateriporus australis Jones and Williams, I967, and L. matesoni Prudhoe, I969 (Cestoda : Dilepididae) from sheathbills, Chionis spp. in Antarctica, with a consideration of infraspecific variation and speciation. $J$. Parasit. 1985, 71, 319326.

Holdgate M. W. : Observations of birds and seals at Anvers Island, Palmer Archipelago, in 1955-57. Br. Antavctic Surv. Bull., I963, 2, 45-51.

Holloway H. L., JR. : Endoparasites of antarctic vertebrates. Antarctic J. U.S., 1967, 2, r99.

Holloway H. L., Jr., Bier J. W. : Notes on the host specificity of Corynosoma hamanni (Linstow, 1892). Bull. Wildlij. Dis. Assoc., 1967, 3, 76-78.

Holloway H. L., Jr., Nickol B. B. : Morphology of the trunk of Corynosoma hamanni (Acanthocephala : Polymorphidae). J. Morphol., 1970, 130, I5I-I62.

Holloway H. L., Jr., Spence J. A. : Ecology of animal parasites in McMurdo Sound, Antarctica. Comp. Physiol. Ecol., 1980, r, 262-284.

Johnston T. H., Best E. W. : Acanthocephaia. Australasian Antarctic Expedition 19I I-I9I4. Science Reports, Series C., Zoology, I937, 10, 5-20.

Johnston T. H., Best E. W. A Astralian Acanthocepha!a. No. 3. Trans. Roy. Soc. S. Aust., I942, $66,250-254$

Johnston T. H., Edmonds S. J. : Australian Acanthocephala. No. 9. Trans. Roy. Soc. S. Aust., I952, 75, I6-2I.

Johnston T. H., Edmonds S. J. : Acanthocephala from Aukland and Campbell Islands. Recs. Dominion Mus., I953, 2, 55-6r.

Johnstone G. W. : Comparative feeding ecology of the giant petrels Macronectes giganteus (Gmelin, and $M$. ha!li (Mathews). In: Adaptations within Antarctic Ecosystems (G. A. Llano. ed.). Gulf Publishing Co., Houston, Texas, 1977, 647-668.

Jones N. V. : The sheathbill, Chionis alba (Gmelin), at Signy Island, South Orkney Islands. Br. Antartic Surv. Bull., 1963, 2, 53-7 I.

Jones N. V., Williams I. C. : The nematode and acanthocephalan parasites of the skieathbill, Chionis alba (Gmelin), at Signy Island, South Orkney Islands and a summary of host-parasite relationships in the sheathbill. J. Helminthol., 1969, 43, 59-67.

Kager N., Asano K., Kinata M. : On the examination against the parasites of antarctic kri!l, Euphausia superba. Sci. Rept. Whales Res. Inst., 1978, 30, 31 I-313.

Knox G. A. : Antarctic marine ecosystems. In : Antarctic Ecology (M. W. Hcldgate, ed.). Academic Press, London, 1970, 69-95. 
Knox G. A., Lowry J. K. : A comparison between the Southern Ocean and the North Polar Ocean with special reference to the Amphipoda and Polychaeta. In : Polar Oceans (M. J. Dunbar, ed.). Arctic Institule N. America, 1977, 423-462.

LAws R. W. : The significance of vertebrates in the Antarctic marine ecosystem. In : Adaptations within Antarctic Ecosystems (G. A. Llano, ed.). Gulf Publishing Co., Houston, Texas, 1977, $4^{\mathrm{II}-43^{8} \text {. }}$

Letper R. T., Atkinson E. L. : Parasitic worms with a note on a free-living nematode. $B r$. Anlarctic (Terra Nova) Expedition, I9Io. Zoology, I9I 5, Vol. 2, 19-60, and plates.

Lowry J. K., Bullock S. : Catalogue of the marine Gammaridean Amphipods of the Southern Ocean. Roy. Soc. N. Z. Bull., I976, I6, I-187.

Markowski S. : On some species of parasitic worms in the Discovery Collections obtained in the years I925-1936. Bull. Br. Mus. Nat. Hist., I97I, 2I, 53-65.

Meyer A. : Acanthocephala. In. Klassen und Ordnungen des Tierreichs (H. G. Bronns), I933, Sec. 2. 582 p.

Nickol B. B., Holloway H. L., JR. : Morphology of the presoma of Corynosoma hamann (Acanthocephala : Polymorphidae). J. Morphol., 1968, 124, 2 I 7-226.

Nikol'skir O. R. : Fauna skrebneii lastonogikh tikhookeanskogo sektora morskoi antarktiki. Izvset. Tikhookean. Nauch. Issledovat, Instit. Rybno. Khoziaii i Okeanog. (TINRO), I974, 88, IOI-IO6.

Parmelee D. F., Fraser W. R., Neilson D. R. : Birds of the Palmer Station area. Antarctic J.U.S., I977, I2, I 4 $2 \mathrm{I}$.

Parmeiee D. F., Bernstein N., Neilson D. R. : Impact of unfavorable ice conditions on bird productivity at Palmer Station during the 1977-78 field season. An:arctic J. U.S., 1978, $I_{3}$, $I_{4} 6-I_{4} 7$.

Petrochenko V. I. : Acanthocephala of domestic and wild animais. Vol. II. Akad. Nauk SSSR Vses. Obshch. Gel'mintol. (English Translation, Israel Prog. Sci. Trans., Jerusalem, I97I). $47^{8} \mathrm{p}$.

Raillet A., Henry A. : Nemathelminthes parasites. Expedition Antarctique Française (1903IG05). J. Charcot., Masson, Paris, I907, I-I5, and plate.

Rausch R. L. : The biology of avian parasites. Chap. 5 Avian Biology. Vol. 8. Academic Press, New York, 1983, 367-442.

Rennie J. : Scotia Collections. On Echinorhynchus antarcticus n. sp. and its ailies. Proc. Roy. Soc., Edinburgh, 1907, 26, 437-446.

Repenning C. A., Ray C. E., Grigorescu D. : Pinniped biogeography. In : Historical biogeography, plate tectonics, and the changing environment. (J. Gray, A. J. Boucout eds.). Oregon State University Press, 1979, 357-369.

Rich P. V. : Antarctic dispersal routes, wandering contments, and the origin of Australia's nonpasseriform avifauna. Mem. Nat. Mus. Victoria (Melbourne), I975, 36, 63-I 24.

Simpson G. G. : Fossil penguins. In : The biology of penguins. (B. Stonehouse ed.). University Park Pvess, London, I975, $555 \mathrm{p}$.

Skriabin A. S., Nikol'skir O. R. : Corynosoma singularis sp. n. (Semiistvo Polymorphidae) parazit morskikh mlekopitaiuschchikh Antarktiki. Nauch. Doklady Vyssh. Shkoly, biol. Nauki, 197 I, II, 7-9.

Target T. E. : Trophic ecology and structure of antarctic fish communities. Marine Ecol. Prog. Ser., I98I, 4, 243-263.

Trivelpiece W., Butler R. G., Volkman N. J. : Feeding territories of brown skuas (Cathavacta lonnbergi). Auk, 1980, $97,669-676$.

Trivelpiece W., Volkman N. J. : Feeding strategies of sympatric south polar Catharacta maccormicki and brown skuas $C$. Jonnbergi. Ibis, I982, $124,50-54$.

Trivelpiece W. Z., Trivelpiece S. G., Volkman N. J., Ware S. H. : Breeding and feeding ecologies of pygoscelid penguins. Antarctic J.U.S., I983, $18,209-2$ ro.

Van Cleave H. J. : Acanthocephala of North American Mammals. Illinois Biol. Monogr., I953, 23, $1-179$.

Volkman N. J., Presler P., Trivelpiece W. : Diets of pygoscelid penguins at King George Island, Antarctica. Condor, 1980, 82, 373-378.

Von Linstow O. : Helminthen von Südgeorgien. Jahrb. Hamb. Wiss. Anat., 1892, 9. 59-77.

Watson G. E. : Birds of the Antarctic and Subantarctic. American Geophysical Union, I975, $359 \mathrm{p}$.

Watson G. E., Angle J. P., Harper P C., Bridge M. A.. Schlatter R. P., Tickell W. L. N., Boyd J. C., Boyd M. M. : Birds of the Antarctic and Subantarctic. Antarctic Map Folio Series I 4. Am. Geog. Soc., I97I, I-I8, and Folio.

Williams I. C., Jones N. V., Payne M. J., Ellis C. : The helminth parasites of the sheathbill, Chionis alba (Gmelin), and the diving petreis, Pelecanoides georgicus (Murphy and Harper) and P. urinaivix (Gmelin) at Bird Island, South Georgia. J. Helminthol., I974, 48, I95-197. 
Woodburne M. O., Zinsmeister W. J. : Fossil land mammal from Antarctica. Science, 1982, 2 I 8 , 284-286.

ZDziтowiecki Z. : Corynosoma shackletoni sp. n. from hosts in South Shetlands and South Georgia (Antarctic). Bull. Acad. Polon. Sci., I978a, 26, 629-634.

ZDzitowiecKi K. : On the occurrence of juvenile acanthocephalans of the genus Corynosoma Lühe, 1904 in fishes off South Georgia and South Shetland Islands (the Antarctic). Acta Ichthyol. et Pisca?. I978b, 8, III-I27.

ZDZITOWIECKI, K. : Some antarctic acanthocephalans of the genus Corynosoma parasitizing Pinnipedia, with descriptions of three new species. Acta Parasitol. Polon., 1984a, 29, 359-377.

ZDzitowiEckI, K. : Redescription of Corynosoma hamanni (Linstow, 1892 ) and description of C. pseudohamanni sp. n. (Acanthocephala) from the environs of the South Shetlands (Antarctic). Acta Parasitol. Polon., I984b, 29, 379-393.

Zdzitowiecki, K. : Acanthocephalans of birds from South Shetlands (Antarctic). Acta Parasitol. Polon., I985, 30, II-24. 